TRB Paper No. 00-1259

\title{
From Here to Efficiency: Time Lags between the Introduction of New Technology and the Achievement of Fuel Savings
}

\author{
Marianne M. Mintz (mmintz@anl.gov) \\ 630-252-5627 (voice) \\ 630-252-3443 (FAX) \\ Anant R.D. Vyas (avyas@anl.gov) \\ 630-252-7578 (voice) \\ 630-252-3443 (FAX) \\ Michael Q.Wang (mwang@anl.gov) \\ 630-252-2819(voice) \\ 630-252-3443 (FAX) \\ Frank Stodolsky (fstodolsky@anl.gov) \\ 202-488-2431 (voice) \\ 202-488-2444 (FAX) \\ Roy M. Cuenca (rcuenca@anl.gov) \\ 630-252-9175 (voice) \\ 630-252-3443 (FAX) \\ Linda L. Gaines (lgaines@anl.gov) \\ 630-252-4919 (voice) \\ 630-252-3443 (FAX)
}

Transportation Technology R\&D Center

Energy Systems Division

Argonne National Laboratory

Argonne, II 60439

\footnotetext{
The submitted manuscript has been created by the University of Chicago as Operator of Argonne National Laboratory ("Argonne") under Contract No. W-31-109-ENG-38 with the U.S. Department of Energy. The U.S. Government retains for itself, and others acting on its behalf, a paid-up, nonexclusive, irrevocable worldwide license in said article to reproduce, prepare derivative works, distribute copies to the public, and pertorm pubficly and display publicly, by or on behalf of the Government.
} 


\section{DISCLAIMER}

This report was prepared as an account of work sponsored by an agency of the United States Government. Neither the United States Government nor any agency thereof, nor any of their employees, make any warranty, express or implied, or assumes any legal liability or responsibility for the accuracy, completeness, or usefuiness of any information, apparatus, product, or process disclosed, or represents that its use would not infringe privately owned rights. Reference herein to any specific commercial product, process, or service by trade name, trademark, manufacturer, or otherwise does not necessarily constitute or imply its endorsement, recommendation, or favoring by the United States Government or any agency thereof. The views and opinions of authors expressed herein do not necessarily state or reflect those of the United States Government or any agency thereof. 


\section{DISCLAIMER}

Portions of this document may be illegible in electronic image products. Images are produced from the best available original document. 


\title{
From Here to Efficiency: Time Lags between the Introduction of New Technology and the Achievement of Fuel Savings*
}

\author{
M. Mintz, A. Vyas, M. Wang, F. Stodolsky, R. Cuenca, and L. Gaines
}

In this paper, the energy savings of new technology offering significant improvements in fuel efficiency are tracked for over 20 years as vehicles incorporating that technology enter the fleet and replace conventional light-duty vehicles. Two separate analyses are discussed: a life-cycle analysis of aluminum-intensive vehicles and a fuel-cycle analysis of the energy and greenhouse gas emissions of double vs. triple fuel-economy vehicles. In both efforts, market-penetration modeling is used to simulate the rate at which new technology enters the new fleet, and stockadjustment modeling is used to capture the inertia in turnover of new and existing current-technology vehicles. Together, these two effects - slowed market penetration and delayed vehicle replacement - increase the time lag between market introduction and the achievement of substantial energy savings. In both cases, 15-20 years elapse before savings approach these levels.

\section{INTRODUCTION}

Time and again, the popular press reports on dramatic efficiency gains of new propulsion technologies or "fuelefficient" variants of existing technologies. From electric vehicles to hybrids to fuel cells, all have at one time or another been touted as the wave of the future. The public (and, perhaps, their elected representatives) accepts these claims, which may or may not be valid, at least in the short run. It doesn't much matter - regardless of the underlying merit of the technology, expectations are raised to impossible-to-achieve levels in the heat of public enthusiasm.

Can we achieve a further ratcheting of fuel economy standards? Sure. Hybrid vehicles already achieve $50 \mathrm{mpg}$. Can we reduce air toxics? Sure. Fuel cells have virtually no emissions. Can we reduce greenhouse gas emissions? Sure. Fuel economy at least double that of today's passenger cars can be achieved with either of these propulsion systems. But are these claims achievable anytime soon? As the following analyses show, the answer is much less clear if the effects of market forces, infrastructure constraints, consumer behavior, and turnover within the stock of current-technology vehicles are considered.

The introduction of new technology is not a quick and clear-cut process. Often, it takes years to identify clear "winners" among competing technologies; even in the absence of such competition, the growth of new technologies can seem painfully slow. Market shares, generally expressed as a percentage of new sales, may grow quickly, but the stock of existing vehicles is not readily replaced. Vehicles are long-lived assets. Even after 10 years of service, fewer than a third of those sold in a given year will have been replaced (American Automobile Manufacturers' Association 1997). As new technologies gain market share, conventional vehicles still command a large, albeit declining, share of new sales. Most of these vehicles will still be on the road when new technologies reach market dominance.

This paper discusses the results of two analyses conducted for the Office of Transportation Technologies within the U.S. Department of Energy. The first looks at the potential energy savings of aluminum-intensive vehicles over their life cycle; the second looks at the potential energy savings of interim technologies, in this case, double vs. triple fuel-economy vehicles. Both analyses include a careful consideration of market penetration, calculate fuelcycle energy savings (and, for aluminum-intensive vehicles, savings from vehicle production as well), and use the same stock survival and usage model. The following discussion describes the two analyses, the penetration assumptions and results, and the stock-modeling approach that was common to both.

\section{Analysis 1: Aluminum-Intensive Vehicles}

Maximizing the use of lightweight materials in body and chassis components holds great promise for improving fuel economy. Automakers have long been interested in substituting such materials as aluminum, magnesium, plastics, and glass-fiber composites for non-structural components. However, much less effort has gone into materials substitution in engine and structural applications. Cost has been prohibitive, both for the materials

\footnotetext{
* Work sponsored by U.S. Department of Energy, Assistant Secretary for Energy Efficiency and Renewable Energy, under contract W-31-109-ENG-38, for the United States Department of Energy.
} 
themselves and for forming them into high-strength body panels and other structural components. In this analysis, it is assumed that $R \& D$ efforts currently under way in this country and abroad will be successful in reducing the cost of producing aluminum for vehicle structures. As a result, an aluminum-intensive vehicle (AIV) will retail for approximately $\$ 1200$ more than a conventional vehicle (CV), once secondary downsizing and volume production are taken into account (i.e., under mature production conditions). Secondary weight-reduction is assumed to be achieved by reducing engine size and power rating, which will maintain the same power-to-weight ratio as that of a $\mathrm{CV}$. The resulting increase in fuel economy (approximately $17-19 \%$ as compared with a comparable $\mathrm{CV}$ ) is expected to eventually offset the AIV's higher purchase price.

Since AIVs initially cost more than CVs but consume less fuel over their lifetimes, consumer interest will vary; some consumers will not buy because of the high initial cost, while others will buy because of the improved fuel economy. Note that the analysis recognized that the incremental cost of AIVs will be much higher than $\$ 1200$ during the introductory phase, and this, in turn, will depress initial market success. A market-penetration model that evaluates consumer and vehicle attributes was employed to project market penetration (Vyas et al. 1989, Stodolsky et al. 1995a). Figure 1 shows the market penetration rates produced by modeling the response of different consumer groups to the attributes of aluminum-intensive vs. conventional cars and light trucks, assuming the former are introduced in 2004 (Stodolsky et al. 1995b). Note that these market shares assume that AIVs compete with conventional vehicles only.

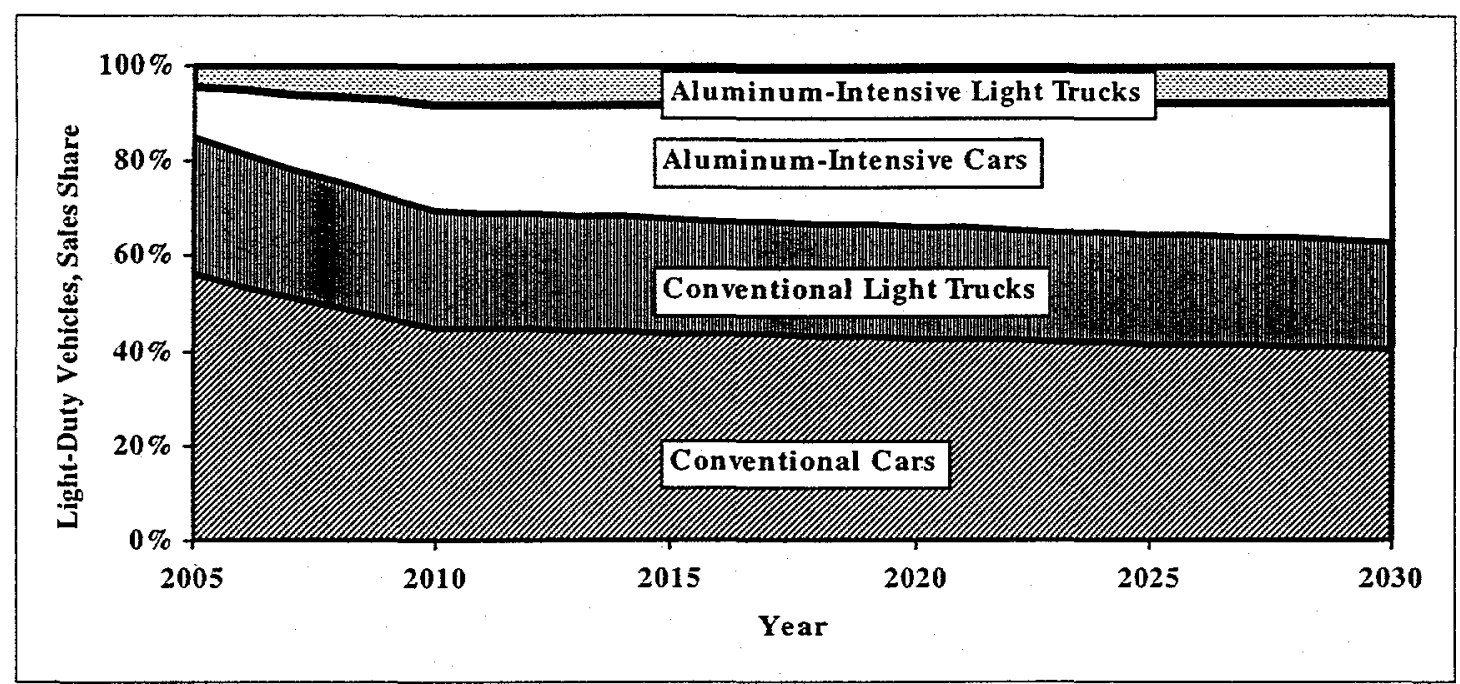

Figure 1 Penetration of New Aluminum-Intensive Vehicles

Life-cycle energy includes all of the energy consumed in the production and use of vehicles (vehicle cycle) and the fuels they consume (fuel cycle). As shown in Figure 2, it includes production of all inputs to fuels and vehicles, production and distribution of fuels and vehicles, vehicle operation, and vehicle disposal/material recovery. Since this is an investigation of materials substitution, analysis of the vehicle cycle (as well as the fuel cycle) is an important component. As shown in Table 1, the baseline, conventional automobile (CV) is assumed to weigh $1441 \mathrm{~kg}(3170 \mathrm{lb})$, and the heaviest AIV is assumed to weigh $981 \mathrm{~kg}(2158 \mathrm{lb})$ after primary and secondary weight reduction.

In addition to weight reduction, the analysis investigated the effect of recycling on the energy required to manufacture CVs vs. AIVs. Although production of vehicle parts from virgin aluminum requires more than 3.5 times the energy input of producing steel parts, there is essentially no energy benefit in producing parts from recycled steel vs. recycled aluminum (Table 2 ). This is a key distinction. Since this analysis tracked vehicles as they were produced (with the materials mix shown in Table 2), entered the fleet, consumed fuel in operation, and eventually were scrapped, the availability of scrap aluminum for AIV production could be explicitly calculated. This is an important improvement over prior analyses in which scrap availability is assumed, often at impossible-toachieve levels. In this analysis, scrap availability is a function of the materials composition of scrapped vehicles and recycling rates. On the basis of current trends and anticipated developments in materials recovery, recycling is 


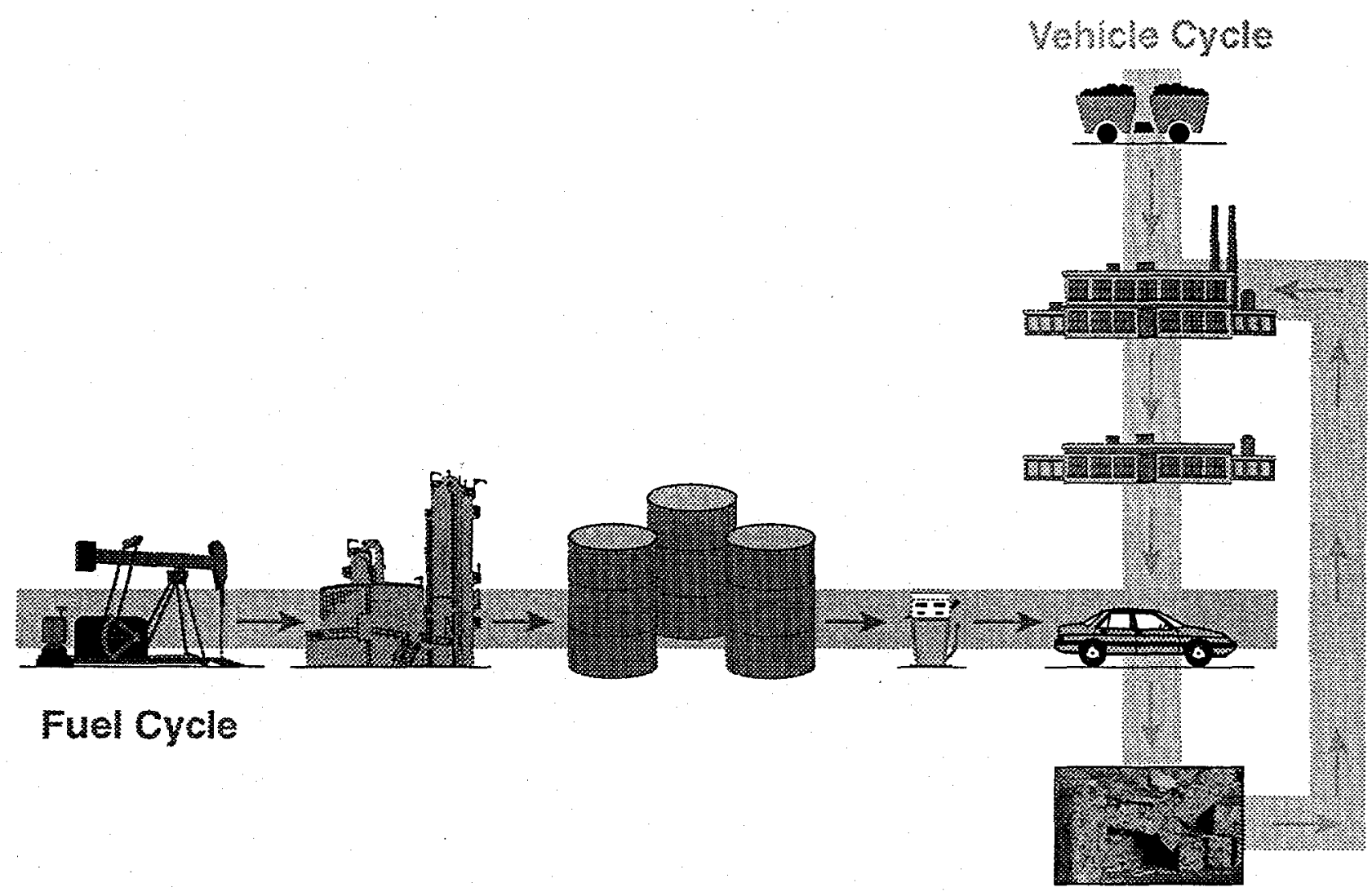

Figure 2 Vehicle And Fuel Cycles: Petroleum-Based Fuels

Table 1 Recycling Rates and Production Energy-Intensity of Aluminum-Intensive-Vehicle Parts from New vs. Recycled Materials $^{\mathbf{a}}$

\begin{tabular}{|c|c|c|c|c|}
\hline \multirow[b]{2}{*}{ Part Material } & \multicolumn{2}{|c|}{$\begin{array}{c}\text { Percent } \\
\text { Recycled }\end{array}$} & \multicolumn{2}{|c|}{$\begin{array}{c}\text { Production } \\
\text { Energy }(\mathrm{MJ} / \mathrm{kg})\end{array}$} \\
\hline & 2005 & 2030 & New & Recycled \\
\hline Steel & 87 & 90 & 65 & 52 \\
\hline Cast iron & 87 & 90 & $r^{b}$ & 37 \\
\hline Wrought aluminum & 93 & 93 & 231 & 52 \\
\hline Cast aluminum & 90 & 90 & $r^{b}$ & 44 \\
\hline Reinforced plastics & 8 & 15 & 56 & 37 \\
\hline Un-reinforced plastics & 20 & 35 & 79 & 14 \\
\hline Copper & 76 & 85 & 140 & 35 \\
\hline Zinc & 5 & 30 & 112 & 8 \\
\hline Powder metal & 0 & 0 & 93 & $\mathrm{n} / \mathrm{r}^{\mathrm{c}}$ \\
\hline Rubber & 0 & 0 & 88 & $n / r^{c}$ \\
\hline Other & 0 & 0 & 88 & $n / r^{c}$ \\
\hline Fluids & 0 & 0 & 88 & $n / r^{c}$ \\
\hline
\end{tabular}

${ }^{a}$ Under a maximum aluminum-substitution scenario.

${ }^{b}$ Assumed produced from recycled scrap.

${ }^{c}$ Assumed not recycled. 
Table 2 Weight of Baseline vs. Aluminum-Intensive Vehicle ${ }^{\mathrm{a}}(\mathrm{kg})$

\begin{tabular}{|c|c|c|c|c|}
\hline \multirow[b]{2}{*}{ Material } & \multirow{2}{*}{$\begin{array}{l}\text { Baseline } \\
\text { Vehicle } \\
\text { Weight }^{\mathrm{b}}\end{array}$} & \multicolumn{3}{|c|}{ Aluminum-Intensive Vehicle } \\
\hline & & $\begin{array}{l}\text { Primary } \\
\text { Weight }\end{array}$ & $\begin{array}{l}\text { Secondary Wt. } \\
\text { Savings }\end{array}$ & $\begin{array}{c}\text { Net } \\
\text { Weight }\end{array}$ \\
\hline Steel & 790 & 186 & (33) & 153 \\
\hline Cast iron & 185 & 54 & (10) & 44 \\
\hline Wrought aluminum ${ }^{e}$ & 17 & 215 & & 215 \\
\hline Cast aluminum & 66 & 252 & (45) & 207 \\
\hline Reinforced plastics ${ }^{f}$ & 14 & 14 & & 14 \\
\hline Un-reinforced plastics & 98 & 98 & & 98 \\
\hline Other & 271 & 271 & (21) & 250 \\
\hline Total & 1441 & 1090 & (109) & 981 \\
\hline Weight reduction & & 351 & 109 & 460 \\
\hline \multicolumn{5}{|c|}{ ander a maximum aluminum-substitution scenario. } \\
\hline \multicolumn{5}{|c|}{ b Baseline vehicle uses a cast-iron engine block and aluminum cylinder head. } \\
\hline \multicolumn{5}{|c|}{$\begin{array}{l}\text { "Assumes savings of } 0.5 \mathrm{~kg} \text { per } \mathrm{kg} \text { of "body-in-white" weight reduction for engine and } \\
\text { chassis components (steel, cast iron, cast aluminum). }\end{array}$} \\
\hline \multirow{2}{*}{\multicolumn{5}{|c|}{$\begin{array}{l}\text { Due to } 20 \% \text { smaller fuel tank capacity and } 3 \% \text { less mass of copper, zinc, glass, and rubber. } \\
\text { e Includes } 14.5 \mathrm{~kg} \text { for radiator and other small components. }\end{array}$}} \\
\hline & & & & \\
\hline \multicolumn{5}{|c|}{$\begin{array}{l}\text { ' Remains the same on a total mass basis, because most plastics (by mass) are used in interior } \\
\text { components, which are assumed to remain unchanged from the baseline. }\end{array}$} \\
\hline
\end{tabular}

assumed to reach near-total levels for steel, cast iron, wrought and cast aluminum, and copper. Thus, by 2030, new AIVs should account for manufacturing as well as operational energy savings.

Figure 3 shows the evolution of fleet-wide, life-cycle energy savings of AIVs using the above-described marketpenetration, weight-reduction, and fuel-efficiency assumptions, along with utilization and scrappage assumptions typical for conventional light-duty vehicles.

Operational energy savings ${ }^{1}$ begin to accrue almost immediately, offsetting increases in manufacturing energy for the first few years. However, by 2016, scrap-wrought aluminum becomes sufficiently plentiful (and the technology for recycling it sufficiently mature) that the energy required to manufacture AIVs becomes essentially equivalent to that required to manufacture CVs. Throughout the period, AIVs continue to cost more because of their higher material cost.

As shown in Figure 3, the full benefit of aluminum substitution is not realized for over 15 years. Not only are savings delayed by vehicle turnover and the lack of recycling infrastructure, but manufacturing energy actually increases in the early years.

\section{Analysis 2: Energy Savings Potential of Transitional Technologies}

Although impressive progress has been made in virtually all of the technologies under development by the Partnership for a New Generation of Vehicles (PNGV), a production-ready prototype has not yet achieved tripled (3X) fuel economy. Recognizing this, the National Research Council's Standing Committee to Review the PNGV Research Program has suggested making a transition from double (2X) fuel economy vehicles to triple (3X) fuel economy vehicles. In its fourth report, the PNGV peer review committee stated that "a strategy of accelerated implementation of the technologies leading to an approximately $60+\mathrm{mpg}$ non-hybrid vehicle, coupled with an expanded research plan to reach the $80 \mathrm{mpg}$ target seems both prudent and feasible" (NRC 1998). Clearly, tripling saves more energy than doubling fuel economy (although the drop in energy use declines from successive efficiency

\footnotetext{
${ }^{1}$ The curve labeled "vehicle use" includes upstream savings from reduced fuel production and distribution.
} 


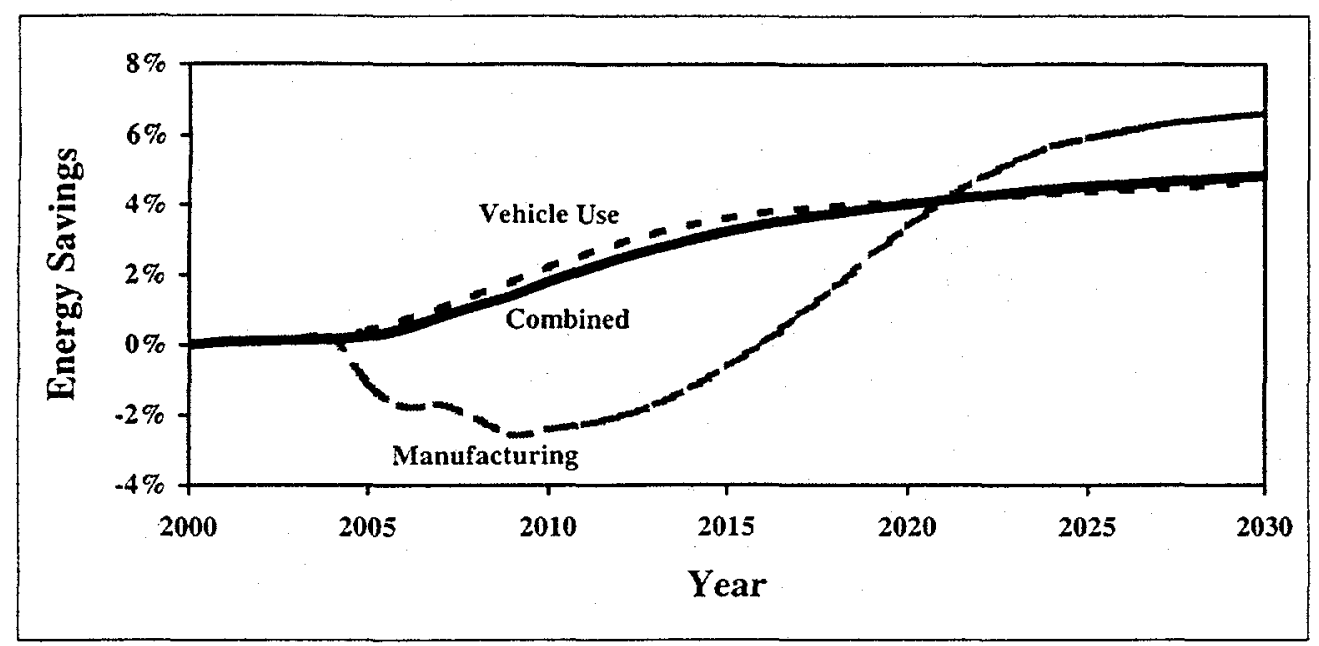

Figure 3 Reduction in LDV Energy Use with Aluminum-Intensive Vehicles

increases). ${ }^{2}$ However, if $2 \mathrm{X}$ vehicles are introduced sooner, even at a slower rate of market penetration, not only will energy savings begin to accrue while research continues on more advanced technologies, but savings will continue to augment the savings from $3 \mathrm{X}$ vehicles once they are introduced.

Following this line of thinking, a reference case and two market-penetration scenarios (a transition and a $3 \mathrm{X}$ only scenario) were devised (see Figs. 4 and 5). The reference case is based on the 1997 Annual Energy Outlook published by the U.S. Department of Energy's Energy Information Administration (1996). The transition scenario assumes that $2 \mathrm{X}$ vehicles are introduced in 2004 and that their share of the new light-duty-vehicle (LDV) market rises to $16 \%$ in 2016 and then becomes asymptotic; $3 X$ vehicles are introduced in 2012 and account for $52 \%$ of new sales by 2030 (in addition to the $17.5 \%$ sales share held by $2 \mathrm{X}$ vehicles). By contrast, in the $3 \mathrm{X}$-only scenario, no dramatic improvement in fuel efficiency occurs until 2010 when $3 \mathrm{X}$ vehicles are introduced. However, in the absence of competition from $2 X$ vehicles, 3X market-share grows to $60 \%$ of new LDV sales in 2030.

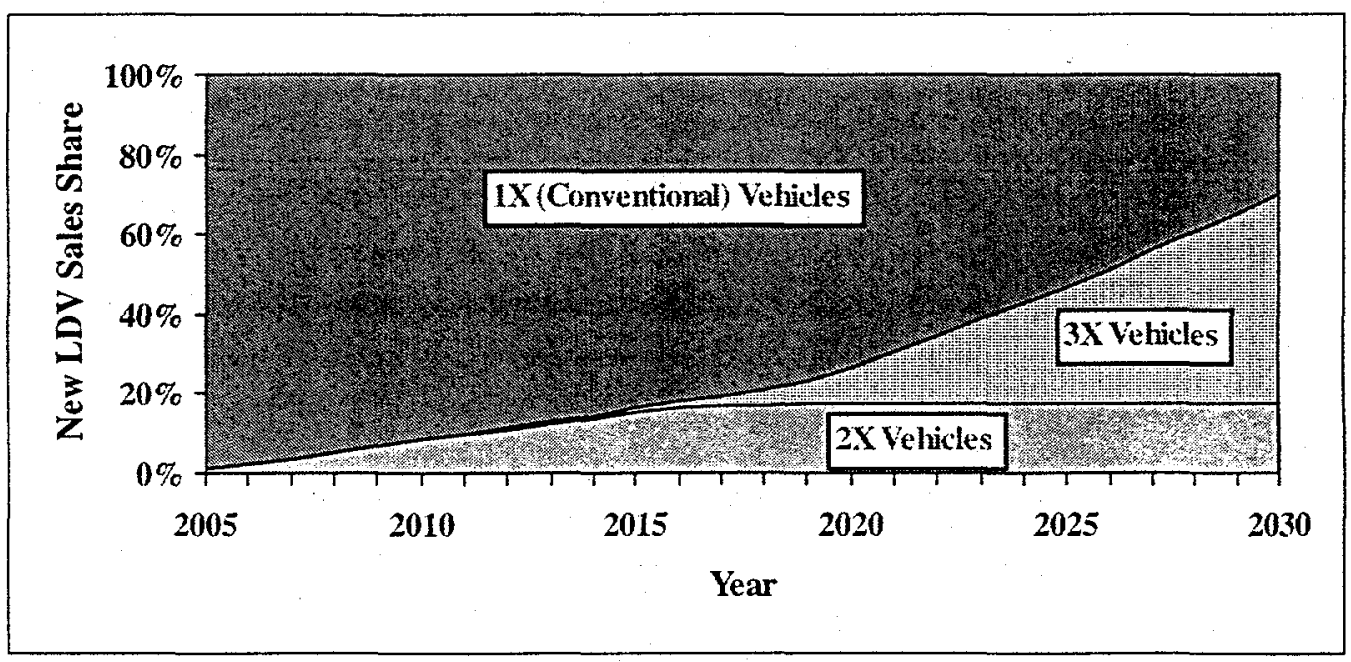

Figure 4 Market Shares under a Transition Scenario

2 For example, doubling baseline fuel-economy results in an increase from 27 to $54 \mathrm{mpg}$, while tripling produces 81 mpg. Expressed in terms of fuel savings potential, doubling yields $50 \%$ savings and tripling yields $66.5 \%$, an incremental increase of only $16.5 \%$. 


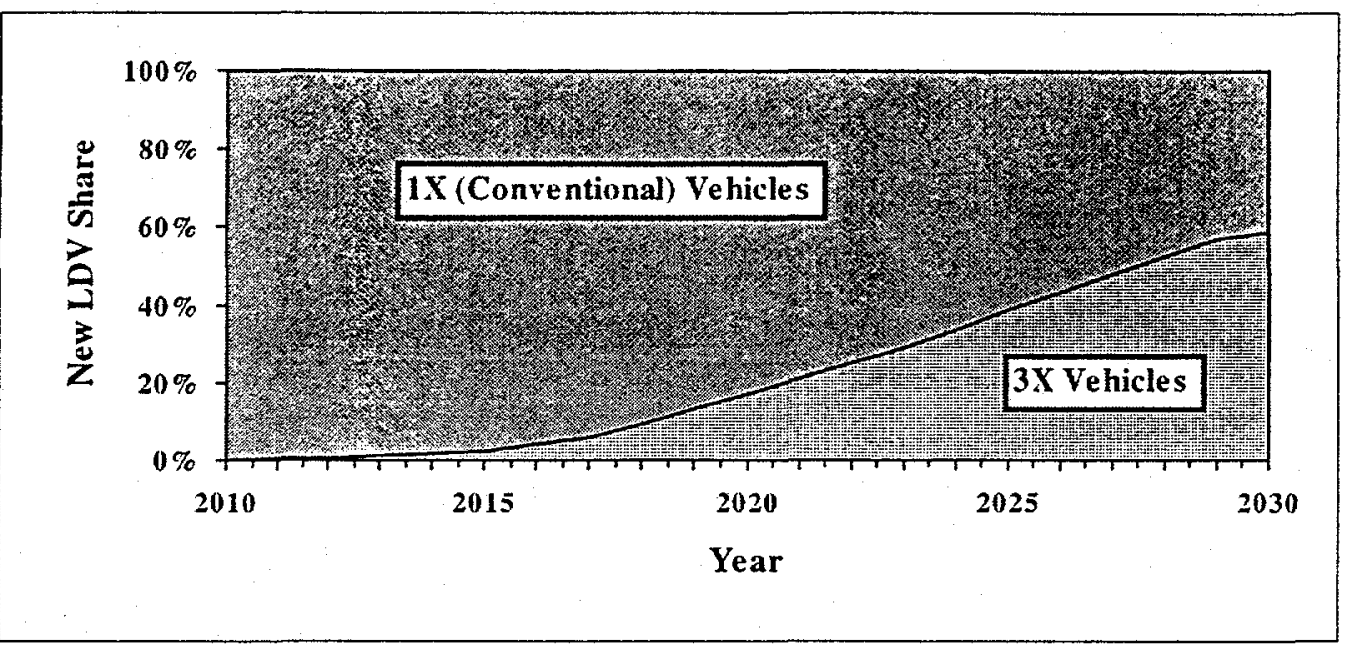

Figure 5 Market Shares under a 3X-Only Scenario

Note that because propulsion-system efficiency is assumed to account for most of the gain between $2 \mathrm{X}$ and $3 \mathrm{X}$ vehicles, the scope of this analysis was limited to the fuel cycle (i.e., energy savings from vehicle operation and fuel production and distribution). As shown in Figure 6, by delaying the introduction of $3 \mathrm{X}$ vehicles, energy savings do not begin to accrue until the second decade of the century. For example, in 2017 , the transition scenario reduces LDV energy use by approximately $5 \%$ from reference case levels (compared with less than $2 \%$ under the $3 \mathrm{X}$-only scenario). This benefit (roughly an additional 3\% savings under the transition scenario) peaks around 2018, but it continues close to that level throughout the forecast period. Even in 2030, the transition scenario continues to have significant energy reductions. Put differently, equivalent savings occur seven years earlier if transition vehicles are introduced and continue to exceed savings (albeit at a diminishing rate) from $3 \mathrm{X}$ vehicles alone throughout the forecast period. Through 2030 , the transition scenario saves 1.7 billion bbls of petroleum as compared with the $3 X$ only scenario ( 5.5 billion bbls as compared with the reference case). By 2030 , the transition scenario reduces reference-case fuel use by over $23 \%$, as compared with approximately $21 \%$ under the $3 \mathrm{X}$-only scenario.

The effect of the transition scenario on greenhouse gases (GHGs) is similar (see Figure 7). As compared with the reference case, $3 \mathrm{X}$ vehicles alone reduce GHGs by over 300 million $\mathrm{MT}$ of $\mathrm{CO}_{2}$-equivalent in 2030 (a combination of $2 \mathrm{X}$ and $3 \mathrm{X}$ vehicles reduce GHGs by 330 million MT). Note that none of the GHG reduction in the $3 \mathrm{X}$-only scenario occurs by 2012 , the final year of the U.S.-Kyoto commitment. However, in the transition scenario, GHGs decline by 30 million MT in 2012 (relative to the reference case).

The implication of these findings is that waiting for a "leap-forward" technology may be counterproductive. Early introduction of intermediate or transitional technology offers an important "bridge" to the future, as well as short-term energy savings (and reductions in GHGs). However, this conclusion is based on the assumption that investment in the transitional technology and its associated infrastructure will be sufficient to permit it to achieve its market potential. This is far from certain. If the technology is clearly transitional (as in the $2 \mathrm{X}$ case), investment may not be forthcoming unless it offers some longer-term advantage vis a vis the eventual market winner. In this line of thinking, investors will "sit on the fence" until it becomes clear which propulsion technology and (especially) which fuel will be the ultimate market winner. Conversely, the transitional technology could enhance the prospects for one or more "leap-forward" candidates by encouraging infrastructure investment that is more readily adapted to that alternative. 


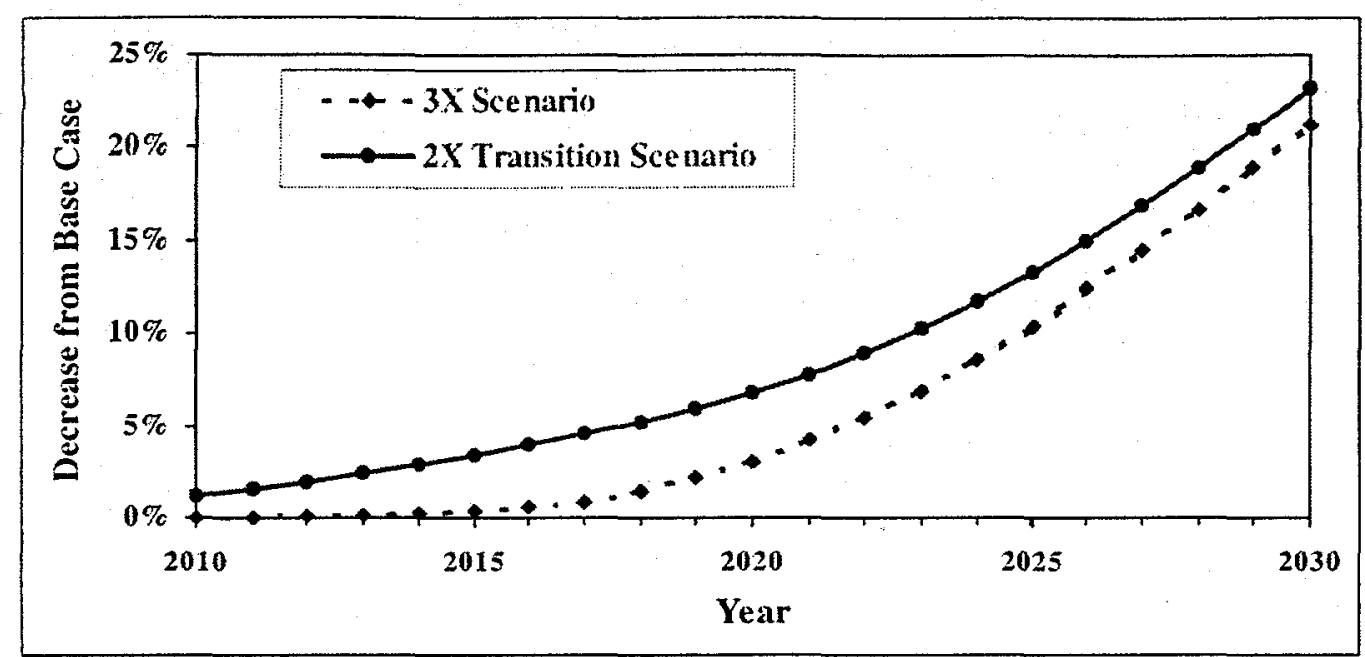

Figure 6 Energy Savings of Transition vs. 3X-Only Scenario

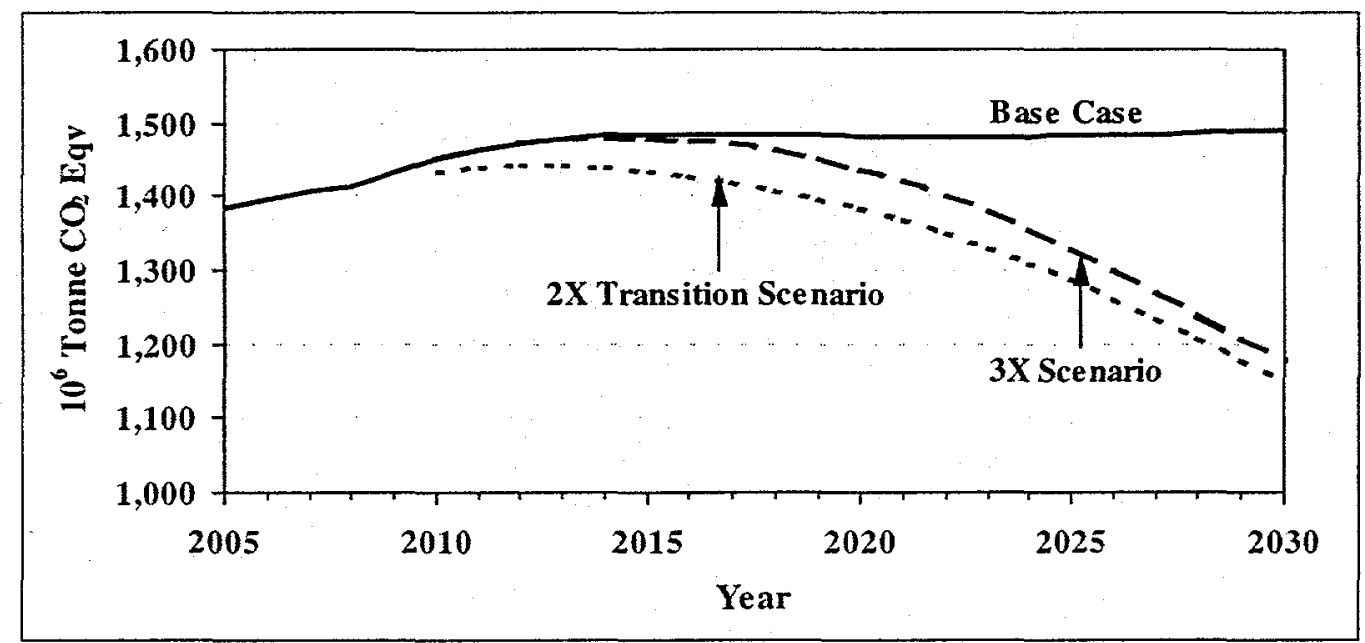

Figure 7 Greenhouse Gas Reductions under Transition and 3X-Only Scenarios

\section{Modeling Approach}

Both analyses used the IMPACTT model to track vehicle stocks, scrappage, rated fuel-economy, and utilization by vintage, which then provided the means to calculate fuel use by all vehicles (advanced and conventional) expected to be on the road in a given forecast year (Mintz et al. 1994, Mintz and Saricks 1998). The IMPACTT model estimates annual energy consumption and emissions production by conventional and advancedtechnology vehicles as they move through the light-duty fleet. IMPACTT incorporates a stock module that adds new vehicles ( $\mathrm{AIV}, \mathrm{CV}, 3 \mathrm{X}$, or $2 \mathrm{X}$ ) and retires old vehicles from an initial vehicle population to produce annual profiles of the auto and light-truck population by age and technology; a usage module to compute auto and lighttruck travel and fuel use by technology; and an emissions module to compute upstream and operational emissions of criteria pollutants and GHGs for autos and light trucks, again by technology. The usage module computes the quantity of petroleum that would have been consumed by CVs in the absence of advanced technologies (reference case); the quantity of petroleum-equivalent consumed by $3 \mathrm{X}, 2 \mathrm{X}$, conventional (1X), and aluminum-intensive vehicles in the particular scenario under investigation; and the net savings due to the presence of advancedtechnology vehicles in the fleet. Upstream energy use is computed post hoc, as a function of operational energy use and a series of rates developed by the Greenhouse gases, Regulated Emissions, and Energy use in Transportation 
(GREET) model (Wang 1996, Wang 1999). For additional discussion of the linkage between IMPACTT and GREET, see Wang et al. (1998). ${ }^{3}$

IMPACTT may be envisioned as a stack of worksheets, one for each technology being examined. Each worksheet includes the stock, usage, and emissions modules shown in Figure 8. Since stock modeling is a key component of IMPACTT, annual travel, fuel use, and emissions of conventional- and advanced-technology vehicles are the sum of vintage-level estimates. This detail is particularly useful for dealing with issues related to fleet turnover, including recycling and comparing alternative market-penetration scenarios.

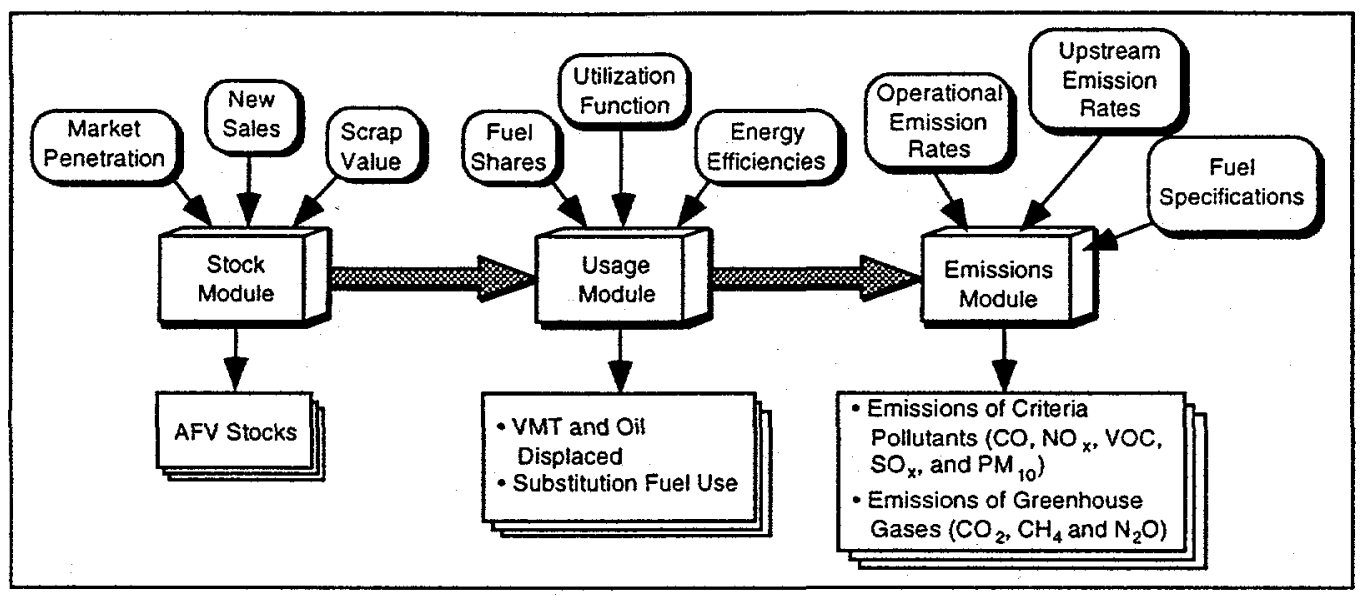

Figure 8 Structure of IMPACTT Model

\section{CONCLUSIONS}

This paper reports findings of two separate analyses in which the energy benefits of advanced technologies are systematically estimated by using market penetration and stock modeling. The latter produces more conservative estimates than in many other analyses, and by taking the subjective element out of the equation, the end result is a more defendable estimate. Stock modeling is an essential element in estimating the speed with which advanced technologies can yield benefits and in quantifying the magnitude of those benefits. Rising market shares can provide a misleading impression that new technologies are rapidly replacing conventional technologies when, in fact, conventional vehicles are and will continue to be the norm for some time to come. In life-cycle analysis, stock modeling is doubly important - to accurately estimate energy use in vehicle operation and to account for material recovery and recycling, which, in turn, affect energy use in vehicle manufacture. Although analysis of historical precedents can, in some cases, substitute for stock modeling per se, the latter is generally more transparent, more reproducible, and more defendable to technical and non-technical audiences.

\section{ACKNOWLEDGMENTS}

This work was sponsored by the Office of Advanced Automotive Technologies (OATT) and the Office of Heavy Vehicle Technologies (OHVT) within the U.S. Department of Energy's Office of Transportation Technologies. The authors thank Ed Wall and James Eberhart for their continued support and input to this work.

\section{REFERENCES}

American Automobile Manufacturers' Association. Motor Vehicle Facts \& Figures 1997. Detroit, 1997.

Mintz, M., M. Tompkins and J. Camp. The IMPACTT Model: Structure and Technical Description. Argonne National Laboratory Report ANL/ESD-TM-93, Dec. 1994.

3 Unlike GREET, IMPACTT's fuel-use module computes only downstream or operational energy use. Upstream energy use is computed as the product of operational energy use and a GREET-supplied rate. 
Mintz, M., and C. Saricks. The IMPACTT5A Model: Enhancements and Modifications Since December 1994. Argonne National Laboratory Report ANL/ESD/TM-154, Sept. 1998.

NRC (National Research Council). Review of the Research Program of the Partnership for a New Generation of Vehicles. Fourth Report, National Academy of Sciences, Washington, D.C., 1998.

Stodolsky, F., A. Vyas and R. Cuenca. Lightweight Materials in the Light-Duty Passenger Vehicle Market: Their Market Penetration Potential and Impacts. Presented at the $2^{\text {nd }}$ World Car Conference, University of California, Riverside, CA, 1995a.

Stodolsky, F., A. Vyas, R. Cuenca and L. Gaines. Life-Cycle Energy Savings Potential from Aluminum-Intensive Vehicles. SAE 951837, Oct. 1995b.

Vyas, A., M. Mintz and Y. Gur. Modeling the Size and Composition of the U.S. Personal Vehicle Fleet. Proc. Intl. Assn. of Science and Technology for Development (IASTED) Intl. Symposium on Applied Simulation and Modeling, Santa Barbara, CA 1989.

Wang, M., M. Mintz, M. Singh, K. Stork, A. Vyas and L. Johnson. Assessment of PNGV Fuels Infrastructure, Phase 2 Report: Additional Capital Needs and Fuel-Cycle Energy and Emissions Impacts. Argonne National Laboratory Report ANL/ESD-37, 1998.

Wang, M.Q. GREET 1.5 - Transportation Fuel Cycle Model, Argonne National Laboratory Report ANL/ESD-39, Aug. 1999.

Wang, M.Q. GREET 1.0 - Transportation Fuel Cycles Model: Methodology and Use. Argonne National Laboratory Report ANL/ESD-33, June 1996.

U.S. Department of Energy, Energy Information Administration. Annual Energy Outlook 1997 with Projections to 2015. DOE/EIA-0383(97), Dec. 1996. 
Figure 1 Penetration of New Aluminum-Intensive Vehicles

Figure 2 Vehicle and Fuel Cycles: Petroleum-Based Fuels

Figure 3 Reduction in LDV Energy Use with Aluminum-Intensive Vehicles

Figure 4 Market Shares under a Transition Scenario

Figure 5 Market Shares under a 3X-Only Scenario

Figure 6 Energy Savings of Transition vs. 3X-Only Scenario

Figure 7 Greenhouse Gas Reductions under Transition and 3X-Only Scenarios

Figure 8 Structure of IMPACTT Model

Table 1 Recycling Rates and Production Energy-Intensity of Aluminum-Intensive-Vehicle Parts from New vs. Recycled Materials ${ }^{a}$

Table 2 Weight of Baseline vs. Aluminum-Intensive Vehicle ${ }^{\mathrm{a}}(\mathrm{kg})$ 